\title{
Affek van toe tot nou: Die erfenis van Herder, Schleiermacher en William James
}

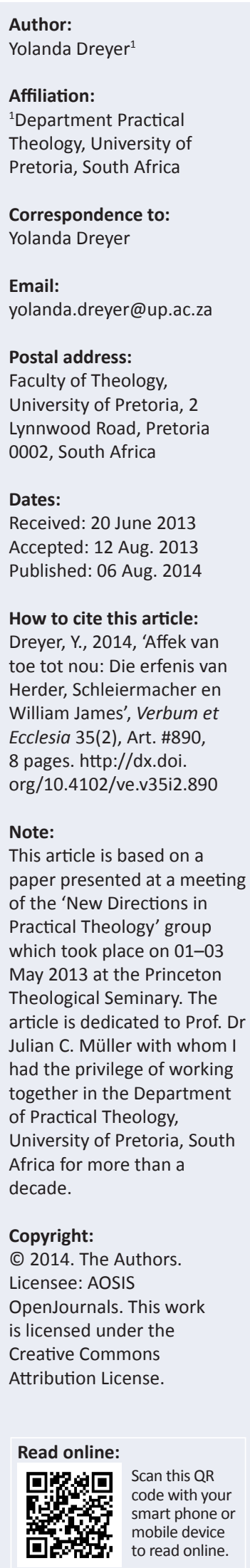

Affect then and now: The heritage of Herder, Schleiermacher and William James. The heritage of Johann Gottfried von Herder (1744-1803), Friedrich Schleiermacher (1768-1834) and William James (1842-1910) is of significance for practical theology. In present-day pastoral care, affect, emotion, feeling and experience are explored by means of, amongst others, narrative theories. In his aesthetics, Herder linked music and literature. Schleiermacher, in his aesthetics, linked his theology of feeling with biography as narrative. Narrativity is central to present-day are theories and praxis in pastoral care. The variety of forms of affect, namely emotion, experience, feeling and mood, has been explored by present-day psychology and psychiatry. These insights can enrich narrative pastoral theories and praxis.

\section{Affek, gevoel, emosie en gemoedstemming}

Emosie is ' $n$ kernfaset van menslike ervaring. Emosie is dinamies en wisselvallig. ' $n$ Onlangse werk oor wisselende emosies (Hermans, Rimé \& Mesquita 2013) ontwikkel 'n dialekties-konstruktivistiese perspektief op die funksionering van mense. Hierdie perspektief beskou emosie as die uitgangspunt vir menslike ervaring, maar dit erken terselfdertyd die belang van betekenisgewing en die narratief. Hierdie benadering beskou emosie en kognisie as nou verweef (Greenberg 2013:223; kyk Greenberg 2010; Greenberg \& Pascual-Leone 1995). Greenberg (2013:223) beklemtoon die dinamiese aard van emosie asook die interaksie tussen ervaring, betekenisgewing en sosiale invloede (kyk Camras \& Schuster 2013:24-30; Tsai 2013:120-126).

Mense gee betekenis aan en orden hulle lewenservarings deur emosie-narratiewe te vertel (kyk Fyvush 2010:88-98). Of hulle hulle emosies suksesvol reguleer, hang af van die mate van hulle welsyn (kyk Woltering \& Lewis 2013:38-39). Om emosie te reguleer, beteken dat 'n mens die intensiteit daarvan moet bestuur (Greenberg 2013:225). Om oor emosionele ervaring na te dink, help mense om sin te maak uit hulle ervaring en om die ervarings by die geheel van hulle lewensverhaal in te sluit.

Hierdie artikel speur die rol van emosie en gevoel in pastoraatteorieë na. Robert Dykstra (2005) bespreek verskillende pastoraatmodelle aan die hand van metafore, soos 'herder', 'nar', 'gewonde geneser', 'afrigter', 'vroedvrou' en 'storieverteller'. Sommige van hierdie modelle fokus op die ontvanger van die pastoraat, ander weer op die pastor en sommige op albei. Eksponente van die onderskeie modelle is praktiese teoloë soos Heije Faber (2005:85-93), Henri Nouwen (2005:6975), Alastair Campbell (2005:94-107), James Dittes (2005:137-150), Jeanne Stevenson Moessner (2005:62-68), Gaylord Noyce (2005:171-179), Karen Hansen (2005:200-208), Edward Wimberly (2005:180-187) en Donald Capps (2005a:188-189). Laasgenoemde is veral bekend vir sy bydrae tot die pastorale psigologie, byvoorbeeld sy werke oor agents of hope [agente van hoop] (Capps 2001, 2005a:188-189). Emosie het tot op hede 'n belangrike rol gespeel in pastoraatteorieë. In Capps (2005b) se boek Fragile connections: Memoires of pastoral care toon hy aan dat pastoraatteorieë 'n ontwikkeling van emosie na gemoedstemming (affek) in die oog het. Hy meld sake soos 'mental disorders' [geestesversteurings], 'abnormal psychology' [abnormale sielkunde] en 'abnormal behaviour' [abnormale gedrag]. Affek sluit onder andere 'anxiety disorders' [angsversteurings], 'mood disorders' [gemoedsversteurings], 'addictive disorders' [afhanklikheidsversteurings], 'schizophrenia' [skisofrenie], 'sexual problems' [seksuele probleme] en 'personality disorders' [persoonlikheidsversteurings] in (kyk Capps 2005b:1-8). Hierdie artikel wil aantoon dat die resente fokus op affek in pastoraatteorieë na die geskiedenis van die teologiese hermeneutiek teruggevoer kan word. Die artikel toon aan dat die fokus op affek in die Romantiese era begin het, spesifiek by die 'teorie van affek', en stel die erfenis van Herder, Schleiermacher en James aan die orde. Dit beskryf ten slotte die invloed wat die onderskeid tussen emosie en gemoedstoestand op die hedendaagse pastoraatteorie het.

Affektenlehre, die teorie van affek, wat as deel van musiekteorie in die Barok-era ontstaan het, is in die Romantiese era uitgebrei. In die laat-Romatiek is daar in die Affektenlehre tussen 'ervaring/ 
emosie' (Erfahrung) en 'gevoel' (Gefühl) onderskei. Die artikel volg die ontwikkeling vanaf die Affektenlehre in die Barokera via die denke van Johann Gottfried von Herder in die Romantiese era tot by die denke van Friedrich Schleiermacher, die vader van die praktiese teologie in die laat-Romantiek. Die artikel bestaan eerstens uit 'n oorsig van die invloed wat Herder se estetiese rasionaliteit op Schleiermacher uitgeoefen het en tweedens op die invloed van Schleiermacher op die empiriese pragmatiek van William James.

\section{Van Herder tot Schleiermacher}

In die teologie was dit Friedrich Schleiermacher (1768-1834) wat die eerste keer tussen emosie of ervaring en gevoel onderskei het deur van die Affektenlehre in die musiek gebruik te maak. Dit was ook hy wat die status van die praktiese teologie as dissipline van theologia applicata (toegepaste teologie) na 'n volwaardige akademiese teologiese dissipline verander het. Hoewel sy fokus hoofsaaklik op die rol van die pastor as leier van 'n gemeente was, het Schleiermacher tog ook 'n breër verstaan van die taak van die praktiese teologie gehad. In die praktiese teologie as die 'teorie van die praxis' word sistematies en krities oor die praktyk nagedink. Hierdie praktyk bestaan nie net uit die kerklike praktyk nie, maar sluit alle Christelike geloofspraktyke as tekens van 'n 'lewende geloof' in. Dit is geloof soos wat dit uitgeleef word en die betekenis wat dit in die lewens van mense in hulle verhouding met God en die wêreld het, asook die implikasies wat geloof vir die kerklike lewe en die gesin, samelewing, kultuur en politiek het (Gräb 2005:185). Schleiermacher beskryf praktiese teoloë as mense in wie 'n kerklike belangstelling en 'n wetenskaplike gees verenig is (Schleiermacher in Gräb 2005:189). Praktiese teoloë gaan krities met die Christelike praktyk om. Schleiermacher se beskrywing van die praktiese teologie is diepgaande beïnvloed deur sy Jesus-studies in die tyd toe hy in Berlyn was waar hy vir baie jare sowel akademikus as pastor was (Clements 1987:19-22). Vir die hedendaagse praktiese teoloog van Berlyn, Wilhelm Gräb (2012:85), is die hart van die praktiese teologie om te ondersoek hoe die simboliese krag van die Christelike geloof mense in staat stel om sin te maak en betekenis te gee aan hulle lewens en om suksesvol met die lewe in vandag se komplekse sosio-kulturele kontekste om te gaan.

Friedrich Schleiermacher is in Breslau (in die hedendaagse Duitsland) as die seun van 'n predikant in die Reformatoriese tradisie gebore. Sy teologiese agtergrond het sowel 'n piëtistiese Herrnhuter as 'n meer liberale humanistiese komponent bevat. Saam met die filosowe Hegel, Nietzsche and Dilthey en die digter Goethe is ook Schleiermacher diepgaande deur die denke van die filosoof Johann Gottfried von Herder (1744-1803) beïnvloed.

Volgens Hans-Georg Gadamer ([1975] 1987:1-51) is 'n multidissiplinêre benadering nodig om affek en emosie te verstaan. Affek en emosie het nie net ' $n$ uitwerking op die individu self nie, maar die effek daarvan strek ook verder as die individu. So 'n multi-dissiplinêre benadering sal byvoorbeeld vakterreine soos taal, musiek, kuns, filosofie, psigologie en godsdiens insluit omdat hulle almal bydra tot die vorming van die tydsgees - 'n gedeelde ideologie, waardes en praktyk (Herder [2006] 2009h:357-382). Schleiermacher het onder andere op Herder se denke oor taal, hermeneutiek, vertaalkunde, denke, kuns, estetika en God gebou (Herder [2006] 2009a:29; vgl. Betti [1962] 1990:177-188).

Herder ([2006] 2009a:6) het'n verskuiwing in filosofiese denke meegebring. Hy beskou metafisiese kennis as nutteloos as dit nie stewig in die empiriese werklikhede van die natuur en die menslike kultuur veranker is nie. Net so is kennis, etiek en moraliteit nutteloos as dit net abstrak bly en nie stewig in die praktyk veranker is nie (vgl. Bernstein 1982:823-845). Hy beskou kuns as 'n medium om 'n invloed op morele gebied uit te oefen (Herder [2006] 2009f:347-357, [2006] 2009g:357382). 'n Narratief, byvoorbeeld, preek nie moraliteit nie, maar karakters wat 'n hoë morele lewenstandaard handhaaf, kan 'n invloed op mense uitoefen. Jesus is so 'n karakter in die Nuwe Testament. Mense ervaar die genade en redding van God in Jesus Christus (Erfahrung des Heils-von-Gott-her-inJesus-Christus) (Barwasser 2010:262).

Herder wat heelwat werk op die terrein van die taalfilosofie gedoen het, beskou die verhouding tussen denke en betekenis as dialekties, nie dualisties nie. Woorde en konsepte het nie betekenis nie, maar verkry betekenis volgens hoe hulle gebruik word. Woorde en konsepte begin by waarneming met die gepaardgaande affektiewe en sensoriese ervaring. Van hierdie woorde of konsepte wat so in konkrete ervaring veranker is, kan later ook meer abstrakte betekenis verkry (Herder [2006] 2009b:31-40). Sulke abstrakte betekenisse kan 'n ideologie tot gevolg hê.

Die insig van Herder wat die rigting van die hermeneutiek verander het, is dat mense só verskil (oor tyd en kultuurgrense heen) dat dit moeilik of selfs onmoontlik is om ander te verstaan sonder om die interpreteerder se eie wêreld af te druk op die wêreld wat sy of hy probeer verstaan en interpreteer. Hierdie insig het later uitgeloop op die idee van die 'hermeneutiese sirkel', dat die horison van die interpreteerder en dié van die geïnterpreteerde versmelt (kyk Dilthey [1894] [1900] 1924:317-358; vgl. Thielen 1999:126; Schloßberger 2005:107). In die interpretasieproses en die toeken van betekenis, word die interpreteerder deur die data geaffekteer. Die hedendaagse resepsie-estetika is 'n gevolg van hierdie denke. David Tracy (1993:73-97) noem so 'n teorie vir die verstaan van die menslike eksistensie 'n 'postmoderne teorie van gesprek' (Theologie als Gespräch) (vgl Barwasser 2010:383; Reiser 2007:40-41).

Herder se hermeneutiek is op die volgende aannames gebou (Herder [2006] 2009d:51-176, [2006] 2009e:177-290):

- Sekulariteit - daar is nie meer 'n onderskeid tussen sakrale en profane hermeneutiek nie.

- Hermeneutiek is universeel en kan verskillend in verskillende dissiplines toegepas word.

- Genre is belangrik vir die verstaan van wat geïnterpreteer word. 
- 'n Verbrede rasionaliteit verg 'n metodologie wat nie net kognitief van aard is nie, maar wat ervaring en die praktyk in ag neem (estetiese rasionaliteit naas kognitiewe rasionaliteit).

- Om te interpreteer deur middel van invoeling (Duits: Einfühlung; Engels: divining) is om die historiese gebeurtenis vandag te herleef deur te voel en ervaar wat die mense van daardie tyd ervaar het toe die gebeurtenis plaasgevind het en om dit te kan doen ten spyte van die groot kloof tussen die tyd, taal, geografie en konteks van toe en nou, maar sonder om die psigologiese fout van oor-identifikasie te begaan.

- Die geheel is meer as die som van die dele.

- Die psigologie kan help om die bedoeling van die spreker of outeur te verstaan.

- 'n Heuristiese benadering is om deur middel van invoeling ' $n$ groter wêreld te ontdek, ook al is min data beskikbaar. Hierdie insig het tot die hedendaagse abduktiewe argumentvoering van die pragmatiek gelei.

Herder (2009f:347-357) se doel was om so getrou moontlik aan die bronteks te bly wat sowel die 'linguistiese' as die 'musikale' aspekte van kommunikasie betref. Daarmee wou hy sowel die estetiese aspek van kommunikasie as die manier waarop dit aan die ervaring ('gevoel' in Schleiermacher se taal) betekenis gee, respekteer (Herder 2009b:31-40). Woorde dra betekenis oor, terwyl musiek sowel betekenis as ervaring en gevoel oordra. Die heuristiek (om die groter wêreld te ontdek) neem albei in ag.

In sy werk On cognition spreek Herder ([1778] 2002:187-244) hom teen dualistiese denke uit. Hy is dit nie eens met die filosoof René Descartes (1596-1650) (in Rodgers 2005:39-40) wat tussen die materiële bestaan (die liggaamlike, gedrag) en denke (mind) skeiding maak nie. Descartes fragmenteer die mens se bestaan en denke: Hy bestudeer gedrag en maak dan logiese afleidings oor denke en bestudeer denke en maak dan logiese afleidings oor gedrag. Vir Herder gaan dit oor die totaliteit van hoe ' $n$ mens dink-en-voel. Vir hom is die mens 'n eenheid ('n trialektiek van kop, hart en hande): Alles is nou met mekaar verweef. Denke word liggaamlik uitgedruk en dit manifesteer weer in gedrag. Hiermee wil Herder dualistiese denke oorstyg. Denke kan nie van die liggaam geskei word nie, maar kan ook nie tot liggaamlike gedrag gereduseer word nie (Herder [1778] 2002:165-166). Nie alle denke mond uit in gedrag nie. Vir Herder ([1778] 2002:165166) sal enige poging om die eenheid van denke-en-voel in die gedrang te bring, tot probleme lei. Kognisie kan ook nie van die wil en affek geskei word nie. Pogings om denke 'suiwer' te hou, 'ongekontamineer' deur gevoel, het nie sin nie (Herder [1778] 2002:187-244). Konsepte, oortuigings en ervaring funksioneer interafhanklik van mekaar. Denke, betekenis en ' $n$ mens se geestesgesteldheid is fundamenteel sosiaal, hoewel die mens ten diepste ook individu is (Herder [1778] 2002:268-271, 272-358, 370-373). Wat in die mens se gees omgaan, is volgens Herder grootliks onbewus en daarom is selfkennis nie vanselfsprekend nie. Op voetspoor van Herder ([1778] 2002) beklemtoon Schleiermacher ook die eenheid tussen liggaam en gees en is hy teen enige vorm van reduksionisme. Om die liggaam tot denke of denke tot liggaamlikheid te reduseer, sou 'lewe' inperk (vgl. Kisner 2008:21).

In sy werk Critical Forests ontwikkel Herder ([2006] 2009d:51176, 2009e:177-290) sy teorie oor die estetika. Skoonheid gaan nie net oor wat visueel mooi is nie, maar verwys na alles wat die siel verheug (Herder [2006] 2009b:31-40). Vir Herder dra kuns tot karakterbou, opvoeding (Bildung) en moraliteit by (kyk Herder [1778] 2002; vgl. Taylor [1991] 1995:79-99). Musiek is besonder kragtig, hoewel die effek daarvan nie altyd net positief is nie (vgl. Adler 1994:55-74).

In sy nadenke oor die geskiedenis fokus Herder op die binnewêreld van historiese figure (vgl. Manuel 1972:211237; Runyan 1988:13). In sy Berlyn-lesings van 1819 is Schleiermacher $([1832] 1864,1864)$ die eerste persoon wat 'n biografie van Jesus konstrueer. Schleiermacher ([1799] 1958) verdedig religie teen die intellektueles van die Romantiek wat daarop neersien. Die fokus het van die kognitiewe na die estetiese verskuif. Die intellektueles beskou religie en die Bybel as kognitief (dit bestaan uit woorde) en daarom waardeloos. Die estetika kan hierteenoor ware betekenis en waarde aan die lewe gee. Kuns is vir die intellektueles die hoogste vorm van insig. Schleiermacher, wat 'n lid van die groep intellektueles was, wil die twee wêrelde bymekaar bring. Hy argumenteer dat religie die dialektiese verbinding tussen die kognitiewe en die estetiese vorm. Bybelfigure kan deur middel van invoeling (Einfühlung) na-geleef word. Deur so met hulle 'saam te voel', kan Bybelfigure (veral Jesus) 'n rolmodel vir moderne mense word (Schleiermacher [1830] [1928] 1976:384). Schleiermacher beskou Jesus as Urbild (Goddelike Bron, God-met-ons) en Vorbild (voorbeeld van ware mensheid) (vgl. Clements 1987:54-55). Op grond van die proloog tot die Johannes-evangelie en die Belydenis van Chalcedon beskou Schleiermacher ([1830] [1928] 1976:740) Jesus as die inkarnasie van God. Jesus kry seer en word gewond. In sy ousia [wese] beskik Jesus oor die Goddelike vermoë om nie net dié te genees wat gewond is nie, maar ook dié wat ander beskadig het. In sy biografiese beskrywing van Schleiermacher stel Keith Clements (1987) dit soos volg (my beklemtoning):

The new life is not generated by the believer, or by the community itself, but is actually imparted through communion with the Jesus in whom it has its source and who is its 'ideal realization'. It must be noted, however, that when Schleiermacher speaks of 'ideality' (Urbildlichkeit) he does not mean an abstract model of perfection, but something nearer the Platonic 'form', that which actually imparts reality to a particular object which participates in it. Also, while Schleiermacher speaks of the 'exemplary' status of Jesus (Vorbildlichkeit) he does not mean a kind of model to be copied, but rather the way in which Jesus himself exemplified the human race by solidarity with it in the fullness of humanity. (pp. 54-55)

Schleiermacher het lesings oor onder andere die psigologie, taal en estetika gegee. Volgens hom gaan taal nie net oor woorde nie en Bybelse taal is nie heilig nie. Verskillende lense is nodig (universele hermeneutiek) om die Bybel te verstaan. Taal, selfs 'innerlike taal', is sosiaal van aard en het 
met kommunikasie te doen. Taal en denke vorm die kern van mense se geestesprosesse. Deur middel van taal en denke orden mense hulle ervaring. Die rol van taal in die Bybel is nie net tegnies nie, maar ook psigologies (vgl. Mueller-Vollmer 1992:72-97). Deur taal word die ervarings en emosies van karakters in hulle volle mensheid uitgedruk. Deur invoeling kan moderne mense hierdie ervarings her-beleef. 'Innerlike taal' is die manier waarop denke, selfbewussyn en persepsie gevorm word. Dit is fundamenteel tot menswees. Hierdie eienskappe kan van ander menslike eienskappe soos gevoel en behoeftes onderskei word. Ervaring lei tot emosies en emosies ry wipplank tussen hoogtes en dieptes, êrens tussen euforie en melancholie. Vir Schleiermacher is dit net 'n diep afhanklikheid van God wat dit moontlik maak om op 'n betekenisvolle manier te midde van wisselende ervaring en emosies te lewe (vgl. Albrecht 1994:109; Schleiermacher [1830] [1928] 1976:16-17). Jesus was die God-menslike wese wat hiertoe in staat was. Invoeling met Jesus is wel vir mense moontlik (vgl. Albrecht 1994:203; Schröder 1996:197).

Estetiese diskoers oor God druk die menslike ervaring van God in die geskiedenis uit, hoewel taal God nie werklik kan beskryf nie. God is nie ' $n$ 'objek' van menslike ervaring nie. Om van God bewus te wees (Gottglaubige Bewußtsein) (Brandt 1941:62), is nie net om oor God na te dink nie, maar ook om oor die mens binne die menslike wêreld na te dink. Die mens se vertroue op God beskryf Schleiermacher ([1830] [1928] 1976:16-17; kyk Brandt 1941:167) as 'n 'gevoel van absolute afhanklikheid'. Volgens Schleiermacher is 'emosie' die menslike reaksie op objekte, op verganklike dinge, terwyl 'gevoel' beteken om van ' $n$ mens se eie eindigheid bewus te wees (vgl. Grondin 1994:71). Wie van eindigheid bewus is, kan nie anders as om die eie swakheid, weerloosheid en sterflikheid te erken nie. Dit is net by God (die oneindige Transendente) waar konstantheid in die menslike lewe moontlik is. Volgens Schleiermacher se holistiese uitgangspunt verkry 'n mens kennis (ook kennis 'van' God) nie net deur die intellek nie. Die intellek word buitendien nie deur die res van menswees onaangeraak gelaat nie onaangeraak gelaat (vgl. Albrecht 1994:126). Die menslike liggaam, sensoriese ervaring, affek en gemoedstemming speel ook 'n rol. Vir Schleiermacher gaan godsdiens nie net oor kennis of oor 'n morele lewe nie, maar ook oor intuïtiewe gevoel. In sy werk On Religion beklemtoon hy dat die wese van religie ' $n$ voortdurende gevoel van afhanklikheid is. Hierdie verhouding met die Transendente is wesenlik vir die mens (Heidegger se Dasein) (vgl. Dumbreck 2012:6168). Gevoel, so verstaan, is sentraal tot wat dit beteken om religieus te wees (Dumbreck 2012:42-48).

Hoe Schleiermacher 'gevoel' verstaan het, verskil van wat vandag onder 'gevoel' of 'emosies' verstaan word. Sy interpretasie is gebaseer op die affekteorie (Affektenlehre) wat uit die filosofiese vakterrein van die estetika stam en wat op antieke teorieë oor die retoriek teruggaan. Volgens die Affektenlehre in die Barok-tyd (1600-1750) kan musiek een spesifieke affek in die hoorder ontlok. In hierdie teorie was die lys van moontlike affekte soos volg: liefde, haat, vreugde, verdriet, verwondering en begeerte. Later is woede, hartseer en jaloesie bygevoeg (kyk Buelow 2004:16). Lorenzo Giacomini (1552-1598) verduidelik hoe affek in die 16de eeu verstaan is, naamlik as "n spirituele beweging of funksie van die gees wat aangetrek of afgestoot word deur'n objek waarmee dit te doen kry' (Giacomini in Gozza 2000:299). Affek so verstaan is nie dieselfde as emosies nie, maar is eerder ' $n$ 'beweging van die gees' (Palisca [1968] 1991:3).

\section{Van Schleiermacher tot James}

In die 19de eeu beweeg Schleiermacher weg van Descartes (18de eeu) se 'Ek dink, daarom bestaan ek', van kognisie na gevoel. Met die oorgang van die 19de na die 20ste eeu pas William James (1842-1910) hierdie verskuiwing op die godsdienspsigologie toe. Sy perspektief op die menslike natuur is pragmaties-empiries. Mense is denkende, ervarende en handelende wesens wat tussen drie bewussyntoestande wissel. Daarom is 'n verskeidenheid religieuse ervarings (varieties of religious experience) moontlik. Ervarings sluit morele waardes en keuses in. James vat hierdie eenheid van ervaring-moraliteit-keuse saam in sy: 'Ek is waaraan ek aandag gee' (I am what I attend to) (kyk Richardson 2007:450).

Hoewel William James se Varieties of religious experience: A study in human nature ([1902] [2002] 2013) 'n klassieke werk in die veld van die godsdienspsigologie is, het dit aanvanklik 'n relatief klein invloed op die ontwikkeling van die vak uitgeoefen. Sommige meen dat die rede hiervoor James se klem op buitengewone en selfs patologiese fenomene is. Volgens ander is sy werk te persoonlik om 'n goeie fondament vir die vak godsdienspsigologie te lê. Die onlangse postmoderne verskuiwing weg van positivistiese psigologie het gelei tot ' $n$ herwaardering van die geskiedenis van die vakgebied wat nou met heelwat meer waardering vir James ondersoek word (kyk Jantzen 2005:89-96). 'n Eenduidige perspektief op die psigologie is nie meer die hoofdoel van die vak nie. Die verskeidenheid benaderings in die vak word nou geredelik aanvaar. Perspektiewe soos sosiale konstruksionisme, hermeneutiek, fenomenologie, asook narratiewe en diskursiewe psigologieë is nou aan die orde van die dag. Volgens Wulff (2005:44-45) het William James die weg hiervoor gebaan.

In 'n onlangse versameling opstelle tydens die eeufeesviering van James se Varieties of religious experience word sy nalatenskap geëer. Jeremy Carrette (2005a:3; vgl. Carrette 2005b:72) meen dat James se werk die grondslag vir die godsdienspsigologie se huidige fokus op emosie gelê het. Volgens Eugene Taylor (2005:11-12) het James verder daartoe bygedra dat empiriese psigologiese fenomene soos drome, hipnose, histerie, veelvuldige persoonlikheid en besetenheid nou vanuit 'n religieuse perspektief deur die godsdienspsigologie geïnterpreteer word. 'n Radikaal empiriese benadering is net moontlik as onderskei word tussen gewone bewussynstoestande en transendentale bewussynstoestande wat mekaar voortdurend afwissel. Hierdie onderskeid tussen die 'fisiese' en die 'metafisiese' vorm deel van die Kantiaanse paradigma (vgl. Taylor 
2005:17-18) waartoe Herder and Schleiermacher bygedra het. Volgens William James behoort religie nie net tot die transendentale sfeer nie, maar is dit ook 'n empiriese sosiale verskynsel. Omgekeerd word religie ook nie net waargeneem nie (empiries), maar is dit ook iets wat op 'n nie-materiële vlak ervaar word. ' $n$ Dialektiese verstaan van religie is dus nodig. Hierdie insig kom van ver af - reeds uit die 19de eeu toe Herder en Schleiermacher die estetiese aspek en effek van kommunikasie in die hermeneutiek erken het. Tekste is uit die perspektief van 'die indruk van skoonheid' benader (Pokorný 2011:108).

Volgens Petr Pokorný (2011:108) is die estetiese aspek van elke teks belangrik. So ook is die inhoudelike analise van elke kunswerk belangrik. Die kognitiewe woord het dus 'n estetiese aspek en die estetiese kuns het 'n kognitiewe aspek. As die estetiese funksie van 'n teks ondersoek word, beteken dit nie dat dit altyd 'mooi' of 'melodieus' hoef te wees nie. Dit beteken dat die teks op emosionele vlak effektief sal wees (Pokorný 2011:109). Met hierdie insig dat 'n teks emosioneel effektief moet wees, word die sirkel van die ontwikkeling van die hermeneutiek voltooi: Herder se insig in die skoonheid van kommunikasie as estetiese kuns; Schleiermacher se dialektiek wat menslike emosie onderskei in óf 'n ongesonde gevoel van afhanklikheid van wat menslik en verganklik is of 'n gesonde gevoel van absolute afhanklikheid van die Transendente; James se insig in die groot verskeidenheid religieuse ervarings, in die empiriese én simboliese wêreld (kyk Hector [2010:215-242] oor die verband tussen Schleiermacher en James).

\section{Emosie en gemoedstoestand}

Die nalatenskap van Herder, Schleiermacher en James het die praktiese teologie ingrypend beïnvloed. Vandag word affek, emosie, gevoel en ervaring veral met behulp van narratiewe teorieë ondersoek. Herder het in sy estetika musiek met letterkunde verbind. In Schleiermacher se estetika het hy die ervaring van God in biografiese narratiewe gevind, veral dié oor Jesus. Van sy grootste teologie is nie in diskursiewe vorm nie, maar in narratiewe vorm geskryf (Schleiermacher [1806] [1826] 2010). Ook in hedendaagse pastoraatteorieë val die fokus op hóé mense hulle verhale vertel. Verhale is die uitdrukking van mense se positiewe én negatiewe emosies. Narratiwiteit het onlosmaaklik deel van pastoraatteorieë en -praktyk geword. Die erfenis van die verskeidenheid vorme van affek, naamlik emosie, ervaring, gevoel en gemoedstoestand, het tot 'n breër visie in die hedendaagse psigologie en psigiatrie gelei. Hierdie insigte kan die fokus op narratiwiteit in pastoraatteorieë en -praktyk verryk. Vervolgens word enkele ontwikkelinge in die psigologie en psigiatrie kortliks bespreek.

As die narratief samehangend is, as daar kognitiewe prosessering plaasvind en as emosies uitgedruk word, word emosies suksesvol gereguleer en 'n hoër vlak van welsyn bereik (Fyvush 2013:14; vgl. Pennebaker \& Chung 2007:263-284).
As die narratief nie net die gebeurtenis in herinnering roep en dit vertel nie, maar ' $n$ aktiewe poging is om betekenis aan die gebeurtenis toe te ken, dra dit tot die kognitiewe herorganisasie en emosionele herstel van 'n persoon by (Rimé 2013:93). Die feit van sosiale interaksie en die deel van ervaring, hoe oppervlakkig ook al, het 'n mate van positiewe effek (kyk Zech \& Rimé 2005:270-287). Om die verhaal te vertel, bring mense nader aan mekaar en versterk sosiale bande. In teenstelling hiermee kan om 'n moeilike emosionele ervaring te onthou, daaroor te tob en dit te vertel sonder om aktief betekenis daaraan toe te ken, tot depressiesimptome en laer vlakke van welsyn lei (Fyvush 2013:15; vgl. NolenHoeksema, Wisco \& Lyubomirsky 2008:400-424; De Rivera \& Páez 2007:233-253).

'n Positiewe emosionele klimaat het 'n goeie uitwerking op mense. 'n Faktor wat daartoe bydra, is dat mense mekaar wedersydse hierin ondersteun (Páez, Espinoza \& Bobwik 2013:119). Op kollektiewe vlak is om 'n negatiewe 'emosionele klimaat' te reguleer, egter nog moeiliker as om individuele negatiewe emosies te reguleer. 'Emosionele klimaat' is die algemene en kollektiewe ervaring van welsyn of 'n gebrek daaraan. Mense se persepsies oor die kollektiewe en persoonlike gevoelens soos byvoorbeeld vrees, vertroue, veiligheid, woede of wanhoop bepaal wat hulle as die emosionele klimaat ervaar (Páez et al. 2013:113-114). Die optrede van sosiale institute, of dit positief of negatief is, dra ook tot die vorming van die emosionele klimaat by. Páez et al. (2013:118) beskryf dit soos volg: Waar 'n groep in hulle verlede kollektief aan wandade skuldig was, is hulle geneig om te glo dat die slagoffers verdien wat hulle aangedoen is. Hulle beskou die slagoffers met minagting en regverdig die dade van die eie groep. Hierteenoor dra 'n amptelike apologie met betrekking tot wandade in die verlede tot ' $n$ positiewer emosionele klimaat by. Die positiewer emosionele klimaat wat die apologie skep, dra ook daartoe by dat die mense meer gewillig is om aan restitusie deel te neem.

'n Verdere onlangse verskuiwing in die studie van emosies is van 'werklike affek' na die ondersoek van wat mense as hulle 'ideale affek' beskou. Die kultuur het 'n groter invloed op die ideale affek as op die werklike affek. Die kultuur dra by tot die vorming van hoe mense graag wil voel. Temperament het egter ' $n$ groter invloed op hoe mense werklik voel as op hoe hulle graag wil voel (Tsai 2013:121). Om 'n werklike positiewe ervaring te hê, kan tot 'n regstelling op 'n moeilike of traumatiese ervaring ten opsigte van ' $n$ individu se emosionele toestand bydra. Greenberg (2013:226) stel dit soos volg: 'Having one's shame met with acceptance and compassion rather than rejection engenders a new feeling en leads to a transformation of shame.'

In studie van menslike affek word tussen 'emosie', 'gemoedstemming' en 'houding' onderskei (kyk Van Mechelen, Verduyn \& Brans 2013:174). Gemoedstemming kan beskryf word as 'n konstante gevoel wat, anders as emosies, nie op 'n spesifieke objek betrekking het nie (Van Mechelen et al. 2013:175; vgl. Frijda et al. 1991:187-225) en as 'n konstante emosionele toestand wat bepaal hoe 'n persoon 
die wêreld ervaar (Lane 2013). 'n Gemoedstoestand of 'bui' as 'n konstante gevoelstoestand kan positief wees ('n goeie bui) of negatief ('n slegte bui) wees. Hoewel 'n goeie bui aangenamer is as 'n slegte een, verteenwoordig enige bui nie optimale geestesgesondheid nie. Om bewus te lewe (mindful), is noodsaaklik vir emosionele welsyn. 'n Bui of gemoedstoestand en bewustelike lewe gaan nie saam nie. Bewuste lewe verg psigiese soepelheid. Om in 'n enkele gemoedstoestand of bui te bly, selfs as dit 'goed' of 'gelukkig' is, getuig van 'n gebrek aan emosionele soepelheid. Sulke mense bly emosioneel op een plek, terwyl die wêreld rondom hulle voortdurend verander. In plaas daarvan dat hulle die gepaste emosionele respons daarop het, bly hulle in een gemoedstemming vassteek. Dit is minder gesond (Orsillo \& Roemer 2011:144).

As ' $n$ persoon se gemoedstemming ernstig ontwrig word, kan dit op 'n gemoedsversteuring dui, waarvan depressie of manie die uiterstes is (American Psychiatric Association [APA] [1987] 2000:943). As die gemoedstemming by die depressiewe uiterste bly, word dit enkelpolêre depressie genoem en wanneer oormatige wisselings in gemoedstemming voorkom, 'n bipolêre versteuring. Laasgenoemde is egter ' $n$ uiters komplekse versteuring en sou beter as 'n multi-polêre versteuring beskryf kon word (kyk Preston 2006:7-40). Gemoedsversteurings ontwrig mense se verhoudingslewe, hulle sosiale interaksie en hulle werkomgewing. Hoewel daar 'n mediese en chemiese aspek is wat deur middel van medikasie behandel kan word, vererger psigologiese faktore soos negatiewe gedagtepatrone en swak eiewaarde die gemoedsversteuring. Die aanleer van hanteringsvaardighede kan sulke mense help om hulle gemoedsversteuring meer effektief te reguleer (Lane 2013).

Milde vorme van 'n gedeprimeerde gemoedstemming verteenwoordig nie noodwendig 'n versteuring nie. Dit kan gewoon die natuurlike reaksie op ontwrigtende lewensomstandighede wees. Mense met volskaalse kliniese depressie verwring egter die werklikheid deur onakkurate denkpatrone. Wat hulle oor die wêreld dink, kom nie met die werklikheid ooreen nie. Wat hulle dink oor die werklikheid, maak hulle moedeloos met daardie werklikheid. Volgens die Kognitiewe Gedragsmodel is hulle gemoedstemming depressief omdat hulle gedagtes depressief is (Ghaemi 2007:122-130). Dit werk wedersyds: Gedagtes affekteer gemoedstemming en gemoedstemming en emosies affekteer gedagtes. Volgens hierdie model beteken terapie om die gedagtewêreld aan te pas en daardeur die gemoedsversteuring te verbeter. 'n Verwronge siening van die werklikheid word gewoonlik nie as gesond beskou nie. Eksponente van die Depressief Realisme Model meen egter dat alle mense, sowel depressief as nie-depressief, die neiging het om hulle werklikheid tot ' $n$ mate te verwring. Sommige mense met ' $n$ milde depressie kan 'n realistieser siening van die werklikheid hê as 'gesonde' nie-depressiewe mense. Laasgenoemde kan 'n hoër vlak van welsyn ervaar, maar dit is op 'n illusie gebaseer.
Volgens die Eksistensiale Psigoterapie behoort effens depressiewe mense aanvaar te word soos hulle is sonder om te probeer om hulle gemoedstemming te verander. Volgens hierdie denke is die fokus op die hier en nou, wat vergelyk kan word met bewuste lewe of 'mindfulness', die gesondste manier van leef. Volgens Ghaemi (2007:122-130) sal hierdie soort terapie meer effektief wees vir mense met gemoedsversteurings. Hierdie benadering respekteer gemoedstemming vir wat dit is, sonder om dit te probeer verander.

\section{Affek en religieuse ervaring}

Die praktiese teoloog en pastoraatkenner Donald Capps het die belang van William James se nalatenskap uitgewys (vgl. o.a. Jacobs \& Capps 1997). Hierdie artikel vind die oorsprong van James se erfenis terug in die werk van Herder en Schleiermacher. Die erfenis van Herder, Schleiermacher en James en die betekenis daarvan vir die teologie en psigologie is ook vir die pastoraat van belang. Om denke te verander, het 'n effek op gevoelens. Om gevoelens te verander, het 'n effek op denke. Veranderde denke en gevoel het weer 'n effek op 'n persoon se self-konsep en ervaring van die werklikheid. Religieuse ervaring is deel van mense se ervaring van die werklikheid - hoe hulle in verhouding tree met hulleself, ander en God. Gesonde gedagtes, gevoelens en self-konsep kan mense help om die gebroke werklikheid waarin hulle leef, beter te hanteer en singewend in 'absolute afhanklikheid van God' daarmee om te gaan. 'n Totale afhanklikheid van die Transendente te midde van wisselende emosies en ervarings kan 'n innerlike stabiliteit en vrede meebring wat nie op ander maniere in hierdie lewenswerklikheid te vind is nie. ' $n$ Totale afhanklikheid van die Transendente kan mense help om hulle self-konsep te verander sodat hulle hulleself kan sien en ervaar as heel mense wat deur God geskape is. Invoeling met God en die na-leef van die Jesus-narratief is die uitdaging vir pastorale beraders wat hierdie teologiese én psigologiese insigte vir hulle teorie en praktyk bruikbaar wil maak.

\section{Erkenning Mededingende belange}

Die outeur verklaar dat sy geen finansiële of persoonlike verbintenisse het met enige partye wat haar nadelig of voordelig kon beïnvloed het in die skryf van hierdie artikel nie.

\section{Literatuurverwysings}

Adler, H., 1994, 'Johann Gottfried Herder's concept of humanity', Studies in EighteenthCentury Culture 23, 55-74. http://dx.doi.org/10.1353/sec.2010.0169

Albrecht, C., 1994, Schleiermachers Theorie der Frömmigkeit: Ihr wissenschaftliche Ort und ihr systematischer Gehalt in den Redden, in der Glaubenslehre und in der Dialektik, De Gruyter, Berlin. http://dx.doi.org/10.1515/9783110878981

American Psychiatric Association, [1987] 2000, Diagnostic and statistical manual of mental disorders, 4th edn., text revised, American Psychiatric Publishing, Washington, DC

Barwasser, C., 2010, Theologie der Kultur und Hermeneutik der Glaubenserfahrung: Zur Gottesfrage und Glaubensverantwortung bei Edward Schillebeeckx OP, Lit Verlag, Berlin. (Religion - Geschichte - Gesellschaft. Fundamentaltheologische Studien, Bd. 47)

Bernstein, R.,1982, 'From hermeneutics to praxis', The Review of Metaphysics 35(4), 823-845. 
Betti, E., [1962] 1990, 'Hermeneutics as the general methodology of the Geisteswissenschaften', transl. J. Bleicher, in G. Ormiston \& A.D. Schrift (eds.), The Geisteswissenschaften, transl. . Bleicher, in G. Ormiston \& A.D. Schrift (eds.), The
hermeneutic tradition from Ast to Ricoeur, pp. 177-188, State University of New hermeneutic tradition fron
York Press, Albany, NY.

Boisen, A., 2001, 'The awful wilderness of the insane', in D. Capps (ed.), Agents of hope: A pastoral psychology, pp. 9-55, Chalice Press, Danvers, MA.

Brandt, R., 1941, The philosophy of Schleiermacher: The development of his theory of scientific and religious knowledge, Greenwood Press Publishers, Westport, CT.

Buelow, G.J., 2004, A history of Baroque music, Indiana University Press, Bloomington, IN.

Campbell, A.V., 2005, 'The wise fool', in R. Dykstra (ed.), Images of pastoral care: Classic reading, pp. 94-107, Chalice Press, Danvers, MA. PMid:15925885

Camras, L.A. \& Shuster, M.M., 2013, 'Children's expressive behavior in different cultural contexts', in D. Hermans, B. Rimé \& B. Mesquita (eds.), Changing emotions, pp. 24-30, Psychology Press, London.

Capps, D., 2001, Agents of hope: A pastoral psychology, Chalice Press, Danvers, MA.

Capps, D., 2005a, 'Introduction', in D. Capps (ed.), Fragile connections: Memoires of pastoral care, pp. 1-8, Chalice Press, Danvers, MA.

Capps, D., 2005b, 'The agent of hope', in R. Dykstra (ed.), Images of pastoral care: Classic reading, pp. 188-199, Chalice Press, Danvers, MA.

Carrette, J.A, 2005a, 'Introduction: The centenary and the varieties of interpretation' in J.A. Carrette (ed.), William James and the varieties of religious experience: A centenary celebration, pp. 1-9, Routledge, London.

Carrette, J.A., 2005b, 'Passionate belief: William James, emotion and religious Experience', in J.A. Carrette (ed.), William James and the varieties of religious experience: A centenary celebration, pp. 72-88, Routledge, London.

Clements, K.W., 1987, Friedrich Schleiermacher: Pioneer of modern theology, Collins, London. (The making of modern theology).

De Rivera, J. \& Páez, D., 2007, 'Emotional climate, human security and culture of peace', Journal of Social Issues 63, 233-253. http://dx.doi.org/10.1111/j.1540 4560.2007.00506.x

Dilthey, W., [1894] [1900] 1924, 'Die Enstehung der Hermeneutik', in W. Dilthey (ed.), Die geistige Welt: Einleitung in die Philosophie des Lebens, Erste Hälfte Gesammelte Schriften, Band V, pp. 317-358, Teubner, Stuttgart.

Dittes, J.E., 2005, 'The ascetic witness', in R. Dykstra (ed.), Images of pastoral care: Classic reading, pp. 137-150, Chalice Press, Danvers, MA.

Dumbreck, G., 2012, Schleiermacher and religious feeling, Peeters, Leuven. (Studies in Philosophical Theology 490).

Dykstra, R., 2005, 'Contemporary and contextual images of care', in R. Dykstra (ed.) Images of pastoral care: Classic reading, pp. 151-160, Chalice Press, Danvers, MA.

Faber, H., 2005, 'The circus clown', in R. Dykstra (ed.), Images of pastoral care: Classic reading, pp. 85-93, Chalice Press, Danvers, MA.

Frijda, N.H., Mesquita, B., Sonnemans, J. \& Van Goozen, S., 1991, 'The duration of affective phenomenon or emotions, sentiments and passions', in K.T. Strongman (ed.), International review of studies on emotion, pp. 187-225, John Wiley \& Sons, Chichester.

Fyvush, R., 2010, 'Speaking silence: The social construction of voice and silence in cultural and autobiographical narratives', Memory 18, 88-98. http://dx.doi. org/10.1080/09658210903029404, PMid:19565405

Fyvush, R., 2013, 'Defining and regulating the self through emotion narratives', in D. Hermans, B. Rimé \& B. Mesquita (eds.), Changing emotions, n.p., Psychology Press, East Sussex.

Gadamer, H-G., [1975] 1987, 'The problem of historical consciousness', Graduate Faculty Philosophy Journal 5(1), 1-51. http://dx.doi.org/10.5840/gfpj1975512

Ghaemi, S.N., 2007, 'Feeling and time: The phenomenology of mood disorders, depressive realism, and existential psychotherapy', Schizophrenia Bulletin 33(1), 122-130. http://dx.doi.org/10.1093/schbul/sbl061, PMid:17122410 PMCid:PMC2632297

Gozza, P., 2000, Number to sound: The musical way to the scientific revolution, Springer, New York. http://dx.doi.org/10.1007/978-94-015-9578-0

Gräb, W., 2005, 'Practical theology as theology of religion: Schleiermacher's understanding of practical theology as a discipline', International Journal of Practical Theology 9(2), 81-196. http://dx.doi.org/10.1515/ijpt.2005.9.2.181

Gräb, W., 2012, 'Practical theology as a religious and cultural hermeneutics of Christian practice: An enthusiastic support of Bonnie J. Miller-McLemore's corrections practice: An enthusiastic support of Bonnie
of the five misunderstandings of practical theology based on Schleiermacher's concept of theology', International Journal for Practical Theology 16(1), 97-92, concept of theology', International Journal for Practicc
http://dx.doi.org/10.1515/ijpt-2012-0007 IJPT 2012

Greenberg, L., 2010, Emotion-focused therapy: Theory and practice, American Psychological Association, Washington, DC.

Greenberg, L., 2013, 'Postscript: Experimental rigor and clinical complexity', in D. Hermans, B. Rimé \& B. Mesquita (eds.), Changing emotions, pp. 223-229, Psychology Press, East Sussex.

Greenberg, L. \& Pascual-Leone, J., 1995, 'A dialectical constructivist approach to experiential change', in R.A. Neimeyer \& M.J. Mahoney (eds.), Constructivism in psychotherapy, pp. 169-191, American Psychological Association, Washington, DC. http://dx.doi.org/10.1037/10170-008

Grondin, J., 1994, Introduction to philosophical hermeneutics, foreword by HansGeorg Gadamer, transl. Joel Weinsheimer, Yale University Press, New Haven, CT. (Yale Studies in Hermeneutics).

Hansen, K., 2005, 'The midwife', in R. Dykstra (ed.), Images of pastoral care: Classic reading, pp. 151-160, Chalice Press, Danvers, MA.
Hector, K.W., 2010, "Attunement" and explication: A pragmatist reading of Schleiermacher's "Theology of Feeling", in B.W. Sockness \& W. Gräb (eds.), Schleiermacher, the study of religion, and the future of theology: A trans-Atlantic Schleiermacher, the study of religion, and
dialogue, pp. 215-242, De Gruyter, Berlin.

Herder, J.G., [2006] 2009a, 'Introduction', in G. Moore (ed.), Johann Gottfried Herder: Selected writings on aesthetics, pp. 1-30, transl. G. Moore, Princeton University Press, Princeton, NJ. PMid:19222132

Herder, J.G., [2006] 2009b, 'Is the beauty of the body a herald of the beauty of the soul?', in G. Moore (ed.), Johann Gottfried Herder: Selected writings on aesthetics, pp. 31-40, transl. G. Moore, Princeton University Press, Princeton, NJ.

Herder, J.G., [2006] 2009d, 'Critical forests, or reflections on the art and science of the beautiful: First grove, dedicated to Mr. Lessing's Laocoön', in G. Moore (ed.), Johann Gottfried Herder: Selected writings on aesthetics, pp. 51-176, transl. G. Moore, Princeton University Press, Princeton, NJ.

Herder, J.G., [2006] 2009e, 'Critical forests: Fourth Grove on Riedel's theory of beaux arts', in G. Moore (ed.), Johann Gottfried Herder: Selected writings on aesthetics, pp. 177-290, transl. G. Moore, Princeton University Press, Princeton, NJ.

Herder, J.G., [2006] 2009f, 'Does painting or music have a greater effect? A divine colloquy', in G. Moore (ed.), Johann Gottfried Herder: Selected writings on aesthetics, pp. 347-357, transl. G. Moore, Princeton University Press, Princeton, NJ.

Herder, J.G., [2006] 2009g, 'Does painting or music have a greater effect? A divine colloquy', in G. Moore (ed.), Johann Gottfried Herder: Selected writings on aesthetics, pp. 347-357, transl. G. Moore, Princeton University Press, Princeton, NJ.

Herder, J.G., [2006] 2009h, 'On image, poetry, and fable', in G. Moore (ed.), Johann Gottfried Herder: Selected writings on aesthetics, pp. 357-382, transl. G. Moore, Princeton University Press, Princeton, NJ.

Herder, J.G., [1778] 2002, 'On the cognition and sensation of the human soul', in M.N. Forster (ed.), Herder: Philosophical writings, pp. 187-244, Cambridge University Press, Cambridge, MA. (Cambridge Texts in the History of Philosophy).

Hermans, D., Rimé, B. \& Mesquita, B. (eds.), 2013, Changing emotions, Psychology Press, East Sussex.

Jacobs, J.L. \& Capps, D. (eds.), 1997, Religion, society and psychoanalysis: Readings in contemporary theory, Westview Press, Boulder, $\mathrm{CO}$.

James, W., [1902] [2002] 2013, The varieties of religious experience: A study in human nature, An electronic classics series, Pennsylvania State University,viewed 21 April 2013, from http://www2.hn.psu.edu/faculty/jmanis/wjames/varieties-relexp.pdf

Jamison, K., 2001, 'It never occurred to me that I was ill', in D. Capps (ed.), Agents of hope: A pastoral psychology, pp. 106-152, Chalice Press, Danvers, MA.

Jantzen, G.M., 2005, 'For an engaged reading: William James and the varieties of postmodern religious experience', in J.A. Carrette (ed.), William James and the varieties of religious experience: A centenary celebration, pp. 89-96, Routledge, London.

Kisner, W., 2008, 'The fourfold revisited: Heideggerian ecological practice and the ontology of things', The Trumpeter 24(3), 2-43.

Lane, C., 2013, Mood disorders, viewed 21 April 2013, from http://www.psyweb.com/ mdisord/jsp/moodd.jsp

Manuel, F.E., 1972, 'The use and abuse of psychology in history', in F. Gilbert \& S. Graubard (eds.), Historical studies today, pp. 211-237, Norton, New York.

Mueller-Vollmer, K., 1992, 'Foundations: General theory and art of interpretation: Friedrich D.E. Schleiermacher', in K. Mueller-Vollmer (ed.), The hermeneutics reader: Texts of the German tradition from the Enlightenment to the present, pp. 72-97, Continuum, New York.

Nolen-Hoeksema, S., Wisco, B.E. \& Lyubomirsky, S., 2008, 'Rethinking rumination', Perspectives on Psychological Science 3, 400-424. http://dx.doi.org/10.1111/ j.1745-6924.2008.00088.x

Nouwen, H.J.M., 2005, 'The wounded healer', in R. Dykstra (ed.), Images of pastoral care: Classic reading, pp. 69-75, Chalice Press, Danvers, MA

Noyce, G., 2005, 'The moral coach and counselor', in R. Dykstra (ed), Images of pastoral care: Classic reading, pp. 171-179, Chalice Press, Danvers, MA.

Orsillo, S.M. \& Roemer, L., 2011, The mindful way through anxiety: Break free from chronic worry and reclaim your life, Guilford Press, New York, viewed 21 April 2013, from http://www.mindfulwaythroughanxietybook.com/

Páez, D., Espinoza, A. \& Bobwik, M., 2013, 'Emotional climate: How it is shaped fostered and changed?', in D. Hermans, B. Rimé \& B. Mesquita (eds.), Changing fostered and changed?', in D. Hermans, B. Rimé \& B.
emotions, pp. 114-119, Psychology Press, East Sussex.

Palisca, C.V., [1968] 1991, Baroque music, Prentice Hall, Upper Saddle River, NJ.

Pennebaker, J.W. \& Chung, C.K., 2007, 'Expressive writing, emotional upheavals, and health', in H.S. Friedman \& R.C. Silver (eds.), Foundations of health psychology, pp. 263-284, Oxford University Press, New York.

Pokorný, P., 2011, Hermeneutics as a theory of understanding, foreword by James $\mathrm{H}$. Charlesworth, William B. Eerdmans, Grand Rapids, MI.

Preston, J.D., 2006, Integrative treatment for borderline personality disorder, New Harbringer Publications, Oakland, CA.

Reiser, M., 2007, Bibelkritik und Auslegung der Heiligen Schrift: Beiträge zur Geschichte der biblischen Exegese und Hermeneutik, Mohr Siebeck, Tübingen. (Wissenschaftliche Untersuchungen zum Neuen Testament 217).

Richardson, R.D., 2007, William James: In the maelstrom of American modernism. A biography, Houghton Mifflin Harcourt, New York.

Rimé, B., 2013, 'Can socially sharing emotions change emotions?', in D. Hermans, B. Rimé \& B. Mesquita (eds.), Changing emotions, pp. 91-96, Psychology Press, East Sussex. 
Rodgers, B.L., 2005, Developing nursing knowledge: Philosophical traditions and Influences, Lippincott Williams \& Wilkins, Ambler, PA.

Runyan, W.M., 1988, 'A historical and conceptual background to psychohistory', in W.M. Runyan (ed.), Psychology and historical interpretation, pp. 3-62, Oxford University Press, Oxford.

Schleiermacher, F.D.E., [1799] 1958, On religion: Speeches to its cultured despisers, transl. J. Oman, Harper \& Bros, New York.

Schleiermacher, F.D.E., [1806] [1826] 2010, Christmas Eve celebration: A dialogue, ed. and transl. T.N. Tice, Wipf \& Stock, Eugene, OR.

Schleiermacher, F.D.E., [1830] [1928] 1976, The Christian faith, transl. of 2nd ed. H.R. Mackintosh \& J.S. Stewart, T \& T Clark, Edinburgh.

Schleiermacher, F.D.E., [1832] 1864, Jesu: Vorlesungen an der Universität zu Berlin im Jahr 1832, ed. K. Rütenik, Reimer Verlag, Berlin.

Schleiermacher, F.D.E., 1864, Das leben Jesu. Sämmtliche Werke 1/6, ed. K.A. Rütenik, Georg Reimer, Berlin.

Schloßberger, M., 2005, Die Erfahrung des Anderer: Gefühle im menschlichen Miteinander, Oldenbourg Akademieverlag, Berlin. http://dx.doi. org/10.1524/9783050047171

Schröder, M., 1996, Die kritische Identität des neuzeitlichen Christentums: Schleiermachers Wesenbestimmung der christlichen Religion, Mohr Siebeck, Tübingen. (Beiträge zur historischen Theology 96).

Stevenson Moessner, J., 2005, 'The self-differentiated Samaritan', in D. Capps (ed.), Agents of hope: A pastoral psychology, pp. 62-68, Chalice Press, Danvers, MA.

Styron, W., 2001, 'A howling tempest in the brain', in D. Capps (ed.), Agents of hope: A pastoral psychology, pp. 56-105, Chalice Press, Danvers, MA.
Taylor, C., [1991] 1995, 'The importance of Herder', in C. Taylor (ed.), Philosophical arguments, pp. 79-99, Harvard University Press, Cambridge, MA.

Taylor, E., 2005, 'Metaphysics and consciousness in James's "Varieties": A centenary lecture', in J. Carrette (ed.), William James and the varieties of religious experience: A centenary celebration, pp. 10-25, Routledge, London. PMid:15666166

Thielen, J., 1999, Wilhelm Dilthey und die Entwicklung des geschichtlichen Denkens in Deutschland im ausgehenden 19. Jahrhundert, Königshausen \& Neumann, Würzburg. PMCid:PMC3301917

Tracy, D., 1993, Theologie als Gespräch: Eine postmoderne Hermeneutik, Grünewald Verlag, Mainz.

Tsai, J.L., 2013, 'Dynamics of ideal affect', in D. Hermans, B. Rimé \& B. Mesquita (eds.), Changing emotions, pp. 120-126, Psychology Press, East Sussex.

Van Mechelen, I., Verduyn, P. \& Brans, K., 2013, 'The duration of emotional episodes', in D. Hermans, B. Rimé \& B. Mesquita (eds.), Changing emotions, pp. 174-180, Psychology Press, East Sussex.

Wimberly, E.P., 2005, 'The indigenous storyteller', in R. Dykstra (ed.), Images of pastoral care: Classic reading, pp. 180-187, Chalice Press, Danvers, MA.

Woltering, S. \& Lewis, M.D., 2013, 'Changing the neural mechanism of emotion regulation in children with behavior problems', in D. Hermans, B. Rimé \& B. Mesquita (eds.), Changing emotions, pp. 37-43, Psychology Press, East Sussex.

Wulff, D.M., 2005, 'Listening to James a century later: The Varieties as a resource for renewing the psychology of religion', in J. Carrette (ed.), William James and the varieties of religious experience: A centenary celebration, pp. 44-53, Routledge, London. PMid:15626496

Zech, E. \& Rimé, B., 2005, 'Is talking about an emotional experience helpful? Effects on emotional recovery and perceived benefits', Clinical Psychology and Psychotherapy 12, 270-287. http://dx.doi.org/10.1002/cpp.460 